Historic, Archive Document

Do not assume content reflects current scientific knowledge, policies, or practices. 



\section{Bulb and Seed News}

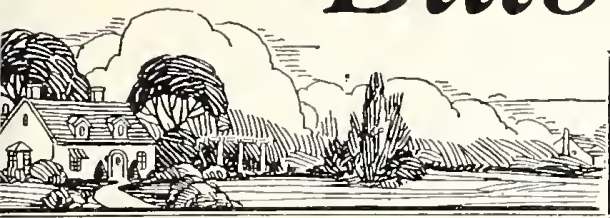

NO. 2

\section{PUBLISHED BY \\ Capitola, California}

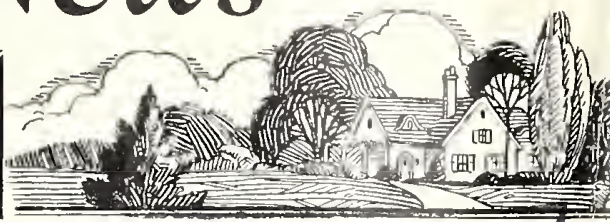

JULY, 1930.

\section{Freesia Bulbs}

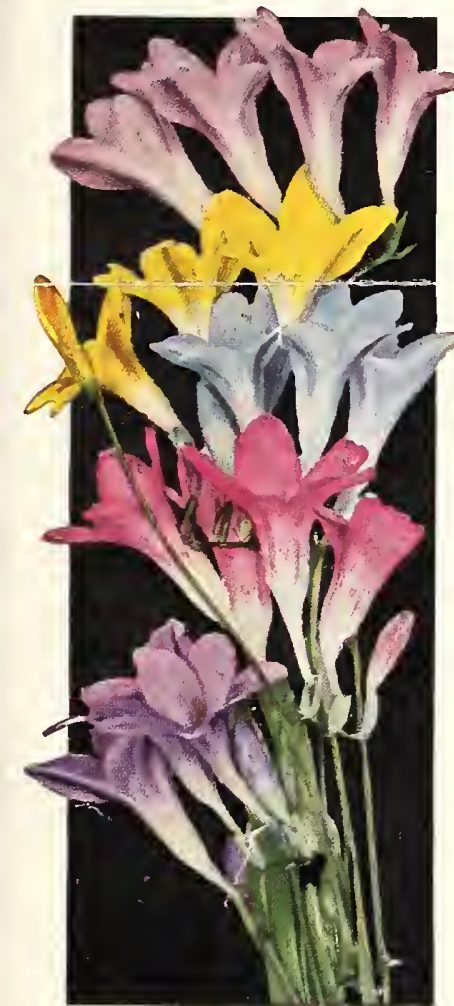

Freesia.

Grape Hyacinths (Muscari)

hat cannot now be imported. HEAVENLY BLUE. Skyblue color. Per 500, $\$ 8.00$; per $1000, \$ 15.00$.

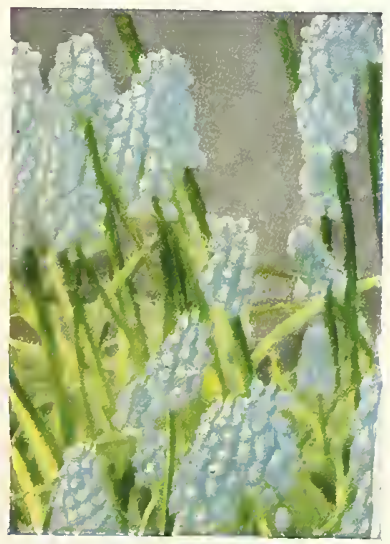

Grape Hyacinth.

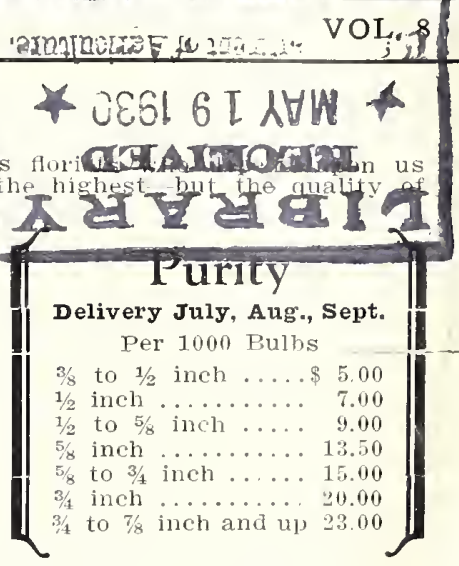

Elliottiana Calla

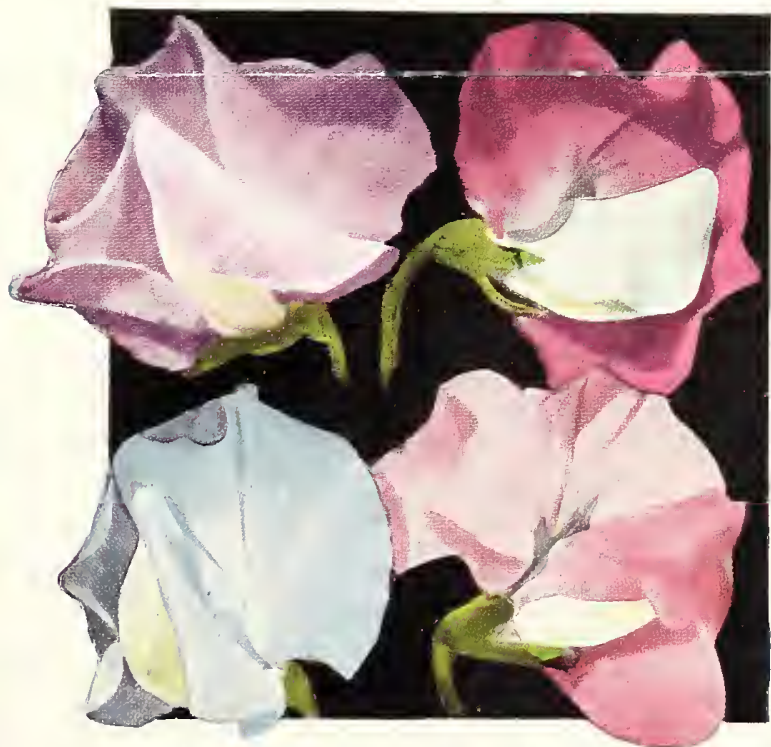

Winter-Ilowering spencer sweet Peas.

\section{Calendula Seed}

BAIL'S ORANGE. $1 / 2$ oz., $\$ 1.50 ; 1$ oz., $\$ 2.50$

IMPROVED SOLID CENTER DARK ORANGE. Petter

\section{Spencer Sweet Pea Seed WINTER FLOWERING}

Any standard sort
$\$ 5.00$ per lb., postpaid.

Snow Storm Improved

Burpee's Orange

Glitters

Haimony

Miss Louise Gude

Mrs. W. G. Farding

$$
\text { the following at 50c per oz.; or }
$$

Mrs. Kerr

Mrs. Chas. Zvolanek

Red Orchid

Zvolanek's Improved Rose

Christmas Pink Orchid

Zvolanek's Blue Sensation
The True Golden Yellow Calla, not the old Lemon Yellow. Fine for cut Winter and spring. Will do well outside if planted after danger of frost is over: Deliver'y after October 1 st. 1 to $1 \frac{1}{2} \mathrm{in.}$ diam. .... \$ $\$ 8.00 \quad \$ 1.4$ $1 \frac{1}{2}$ to $1 \frac{3}{4} \mathrm{in.}$ diam. ..... $10.00 \quad 1.60$ $13 / 4$ to 2 in. diam.

$21 / 4$ to $21 / 2$ in. diam.

12.000
14.00 2.25

SPOTTED IEAF WHITE CALLA Richardia Alba Maculata

Green leaves with white spots the same as the yellow Calla. Bulbs a.l Flowers type as yellow Calla buip.

are the same as for yellow calla bulos.

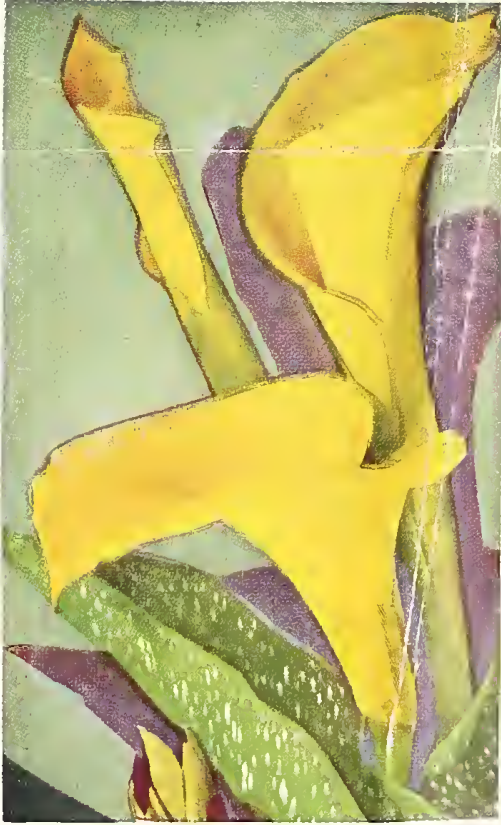

Golden Yellow Calla. 


\section{Tuberous Rooted Begonia Bulbs}

Wonderful for Mother's Day and Spring sales. Also for bedding Delivery after December 1st. Reserve now. Doubles, Singles, Frilled and Ruffled edges. Eleven colors. 1 to $1 \frac{1}{2}$ inch diameter, $\$ 4.50$ per $50 ; \$ 8.00$ per 100 . Delivered for $50 \mathrm{c}$.

\section{Watsonia}

Similar to Gladiolus but spikes longer and have several spikes to ach bulb. Fine for forcing; will make more money for you than gladioli. Large, pure white. Price, $\$ 16.00$ per 500; \$30.00 per 1000 . Delivery earlier than gladioli. We ean ship in September and you an plant October 1 st and secure early flowers when they are worth real moner.

\section{Scillas}

The Scilla we grow is the new extra large flowered and tall grower IARGE DARK BLUE. Price, per 500 bulbs, $\$ 9.00$; per 1000 bulbs, $\$ 16.00$.

\section{Aethiopica Calla}

The old White Calla

Calla Lilies pay florists good returns. The bulbs are good for several years and are easy

to grow.

inch circumferenee

to 4 inch eircumference

inch circumference.

to 8 inch eircumference.

\section{Godfrey Calla}

Smaller bulb than the common white Calla, but produces whiter blooms and is a free bloomer. Size is by circumference. All blooming sizes he first year.

inch circumference

to 3 inch eircumference

to 4 inch circumference

to 6 inch circumference

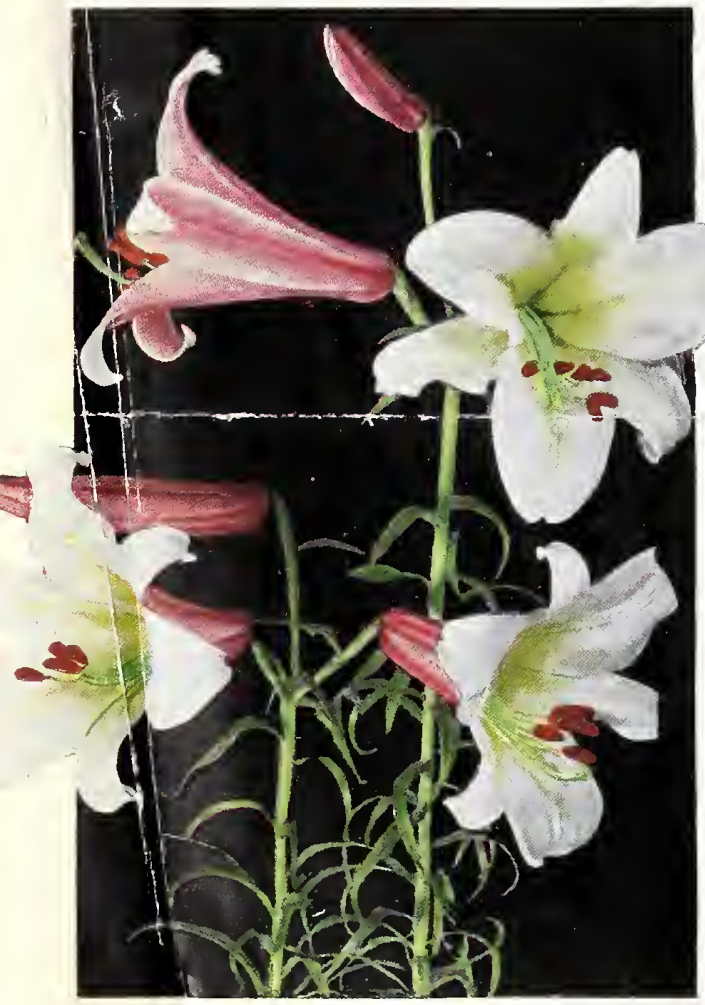

Per 100
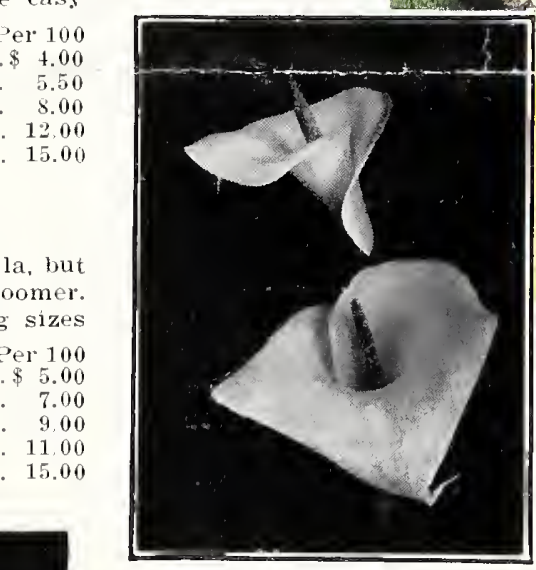

Old White Calla.

\section{Regale}

Strong young bulbs. All will flower first season.

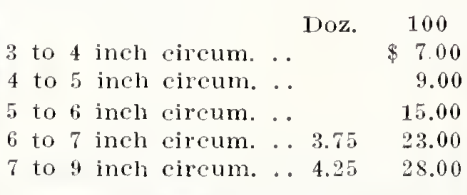

\section{Gladioli}

Treated for Early Forcing.

Delivery in October, November. December and January.

HALLEY. Early; sal- $\$ 2.25 \$ 20.00$ mon-pink $\ldots$..........

Early; coral-pink .....

Fосн. Large, early

pink .................

FEACH BLOW. Early;

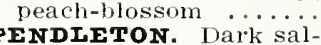

mon ....................

ALICE TIPL ADY. Large:

virkinIA. New; red $\ldots 2.25$

PRIN CIPINE. Early

bright red . Flesh

NIAGARA. Cream-yellow. 2.25

Regal lily.

\section{$2.50 \quad 22.00$}

2.25

2.7525 .00

$75 \quad 25.00$

20.00

25.00

20.00

20.00

20.00

23.00

\section{Poetaz and Paper White}

Several flowers to each stem.

IAURENS KOSTER. Pure white,

with orange-yellow eye;

crinkled ..................

ELVIRA. Pure white, yel-
low eye. Large, ruffled

flowers .........

PAPER-W HITES.

$13 / 8$ to $1 \frac{1}{2}$ inch diameter. $2.50 \quad 22.00$

$1 \frac{1 / 2}{20} 2$ inch diameter ... $3.80 \quad 36,00$

\section{Triteleia}

TRITELEIA VIOLACEA.

Each bulb produces a

large number of blooming

plants. The bulbs are

about $5 / 8$ to $3 / 4$ size and

resemble a rescia hats.

of a nice green shade.

Flowers are violet-blue

and star shape. You will

find them profitable if

forced, as they will

bloom about Christmas.

Cool temperature is best

when forced, about same

as freesias ...........\$2.00 \$16.00

\section{Montebretias}

FIRE KING. Fed ......... 100

AURANTIACA. Orange-yellow 3.00

Califormia. Clear yellow ..... 3.00

GOLDEN WEST. Golden yellow .. 4.00

LORD NELSON. Large orange . . . 5.00

TALISMAN. Dark searlet $\ldots \ldots, 4.00$

GERMANIA. Red and yellow .... 3.50

KING EDMUND. Yellow ........ 5.00

WESTWICK. Orange with yellow

AIL SORTS MIXED 